EXTENDED REPORT

\title{
Knowledge and beliefs on corneal donation in Singapore adults
}

\author{
Y-W Yew, S-M Saw, J C-H Pan, H-M Shen, M Lwin, M-S Yew, W-J Heng
}

Br J Ophthalmol 2005;89:835-840. doi: 10.1136/bjo.2004.057372

See end of article for authors' affiliations

......................

Correspondence to: Seang-Mei Saw, MBBS, $\mathrm{MPH}, \mathrm{PhD}$, Department of Community, Occupational and Family Medicine, National University of Singapore, 16 Medical Drive, Singapore 117597; cofsawsm@nus.edu.sg

Accepted for publication 29 November 2004

\begin{abstract}
Aim: To assess the knowledge and willingness of Singapore adults towards corneal donation.
Methods: The study population consists of a cluster random sample of the population living in Bedok North (an area in the eastern part of Singapore). The study population comprised residents aged 21-65 years living in 675 randomly sampled housing units. The participation rate was $65.9 \%$ (544/825). All participants were interviewed face to face with a questionnaire formulated according to the modified Horton and Horton model. Knowledge, values, attitudes, and spiritual beliefs of participants were assessed to evaluate their willingness to donate their corneas.

Results: $67.0 \%$ of participants were willing to donate their corneas. Ethnicity (Chinese) and religion (Christians, Hindus, or those with no religion) were associated with increased willingness to donate corneas. Greater knowledge and increased altruistic values were also associated with increased willingness to donate corneas.

Conclusion: A proportion of participants were willing to donate their corneas. Awareness of corneal donation is high but specific knowledge should be further increased among adults.
\end{abstract}

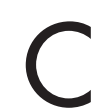
orneal transplant is a sight saving procedure and is the most common type of human transplant surgery. Indications for cornea transplant include bullous keratopathy, regrafts, corneal dystrophies, and keratoconus.

Relatively few studies have described the characteristics and motivation of potential donors of corneas.

Two studies done in north western India ${ }^{1}$ and Hyderabad, India, ${ }^{2}$ specifically examine the attitudes towards corneal donation and awareness of corneal donation, respectively. Both the north western India $(n=2000)$ and the Hyderabad $(\mathrm{n}=2954)$ study included individuals from a wide age range (>15 and 18-99 years) and all participants were Hindus, Sikhs, or Muslims. Another study done in Toronto, Canada, ${ }^{3}$ examined the public attitudes towards donation of body parts with particular emphasis on the eye. This Toronto $(n=595)$ study includes individuals who are above 16 years but it only examines the level of willingness towards donation of body parts and not just corneal donation. Therefore, there was a need to address the knowledge, attitudes, and beliefs regarding corneal donation in a multiracial Asian society like Singapore. In this paper, we aimed to assess the willingness of Singapore adults to donate their corneas as well as to determine the factors influencing their willingness. We hoped to identify the demographics of Singapore adults who may be less inclined to donate their corneas.

\section{MATERIALS AND METHODS}

A community based cross sectional study was conducted in the eastern part of Singapore in Bedok North Estate. This study was part of a third year National University of Singapore third year medical student research posting.

\section{Study population}

We included all residents who are Singapore citizens and permanent residents aged between 21-65 years old living in the sampled housing units at the time of our study. We excluded residents with physical or mental illnesses, which may impair their ability to communicate or respond logically. Written informed consent was obtained after the nature of the study was explained to the participants. The study was approved by the Department of Community, Occupational and Family Medicine, Student Project Committee.

The sampling frame consists of a total of 8314 household units. One stage random cluster sampling was done, and 675 housing units were sampled. Non-participating household units and individuals consisted of those who refused to participate in the study or who were non-contactable. Failure to contact the household or individual after at least three revisits (at three different times of the day) will deem the household or individual as non-contactable. The household participation rate was $(369 / 551=67.0 \%)$ and the individual participation rate was $65.9 \%(544 / 825)$.

\section{Questionnaire based data}

The questionnaire was developed with the aid of focus group discussions consisting of six participants aged 20-57 years old, encompassing all four races as well as the main religions in Singapore. Open ended questions were asked to generate ideas on possible views and opinions towards cornea donation and ideas gathered were used to develop the questionnaire. A pilot study in 67 adults was then conducted in order to assess the clarity and ease of comprehension of the questionnaire. Interviewer training was also conducted before the survey proper commenced.

We adapted Horton and Horton's ${ }^{4}$ basic model of people's willingness to become potential donors in the development of our questionnaire. As proposed in the modified Horton and Horton's model, ${ }^{5}$ knowledge, values and spiritual beliefs influence a person's attitude towards cornea donation, and are mediating factors that lead to a person's willingness to donate. Other questions asked about corneal donation include whether participants have heard about corneal donation and whether approval of close relatives and friends is important in one's decision to donate corneas.

Other information in the questionnaire included demographic data (name, identification card number, age, sex, race, religion, marital status, educational status, housing type, monthly household income, and occupation).

Eligible individuals in the chosen housing units were interviewed face to face via a questionnaire. The average 
length of the interview was about 20 minutes. The questionnaire was translated into Chinese and Malay. A glossary was included and each interviewer was equipped with Chinese and Malay translations of the questionnaire.

\section{Data analysis}

Data analysis was conducted using Statistical Package for Social Sciences (SPSS) Version 12.0. Descriptive, univariate, and multivariate analyses were then performed.

The characteristics of those who were willing to donate corneas were compared to those who were not willing. Proportions were compared using the $\chi^{2}$ test and means using the $t$ test or medians using the Wilcoxon rank sum test, if parametric assumptions were not met. Statistical significance was determined at the 0.05 level.

\section{RESULTS}

\section{Demographic profile of respondents}

The age distribution of the participants was as follows: 201 (35.6\%) were $21-35$ years old, $221(39.2 \%)$ were $36-50$ years old, and $143(25.2 \%)$ aged 51-65 years. There were 288 $(51.1 \%)$ males and $278(48.9 \%)$ females. There were 371 $(65.8 \%)$ married, $164(29.1 \%)$ single, 20 (3.5\%) divorced or separated, and nine (1.6\%) widowed participants. The ethnicity distribution of participants was as follows: 390 Chinese (69.1\%), 143 Malays (25.4\%), 25 Indians (4.4\%), and six from other races $(1.1 \%)$. The completed education level of the participants was as follows: $13.0 \%$ had no formal education, $21.1 \%$ primary school education (ages 612 years), $41.5 \%$ secondary school education (ages 1316 years), and $34.3 \%$ had completed pre-university or tertiary education (ages 17 years and above).

\section{Willingness to donate}

In all, $364(67 \%)$ out of a total of 544 indicated that they were willing to donate their corneas. A similar proportion of participants $(68 \%)$ were willing to donate other organs.

Table 1 reflects the demographics of respondents who were willing to donate their corneas, according to age, sex, race, religion, and education level. Willingness to donate was not associated with age $(p=0.12)$ or $\operatorname{sex}(p=0.81)$. Chinese people were the most willing to donate, with $75.3 \%$ of the Chinese interviewed willing to donate. Malays were the least willing, with only $44.4 \%$ of Malay respondents willing to donate $(\mathrm{p}<0.001)$. Atheists $(84.4 \%, \mathrm{p}<0.001)$ were the most willing to donate their corneas; $75.6 \%$ of those who completed tertiary education were willing to donate compared to only $52.9 \%$ of those who have no formal education $(p=0.012)$. In the final multiple logistic regression model (table 2), race remained significantly associated with willingness to donate corneas after controlling for age, sex, and educational level. Similarly, religion remained significantly associated with willingness to donate corneas, after adjusting for age, sex, and educational level. Educational level was no longer significantly associated with willingness to donate corneas, after controlling for age, sex, and religion.

\section{Reasons for willingness to donate corneas}

Among those who were willing to donate their corneas, $92.9 \%$ did so because they thought that donating a part of themselves after death made them feel they were doing good (table 3). Other reasons cited for their willingness to donate included hearing good results from cornea transplants $(47.8 \%)$ or having read an article or heard a speaker talk about the topic $(47.0 \%)$.

The most common reason cited by those who were unwilling to donate their corneas was that they preferred that their bodies remained intact after death (73.2\%). Other reasons cited included that their families may be upset $(49.2 \%)$ or the fear that their bodies would not be treated with respect $(49.2 \%)$ (table 4$)$.

\section{Knowledge}

Awareness of corneal donation

in all, $80.7 \%$ of all respondents had heard of corneal donation. Chinese people $(86.6 \%)$ were more aware of corneal donation than Malays $(71.1 \%)$ and other races $(51.6 \%)(\mathrm{p}<0.001)$. Christians $(88.7 \%)$ were the most aware

\begin{tabular}{|c|c|c|c|}
\hline \multirow[b]{2}{*}{ Demographics } & \multirow{2}{*}{$\begin{array}{l}\text { Willing to } \\
\text { donate } \\
\text { No (\%) }\end{array}$} & \multirow{2}{*}{$\begin{array}{l}\begin{array}{l}\text { Unwilling to } \\
\text { donate }\end{array} \\
\text { No (\%) }\end{array}$} & \multirow[b]{2}{*}{ p Value } \\
\hline & & & \\
\hline Total & $364(67.0)$ & $180(33.0)$ & \\
\hline \multicolumn{4}{|l|}{ Age (years) } \\
\hline $21-30$ & $101(71.1)$ & $41(28.9)$ & 0.21 \\
\hline $31-40$ & $91(70.0)$ & $39(30.0)$ & \\
\hline $41-50$ & $79(59.8)$ & $53(40.2)$ & \\
\hline $51-60$ & 73 (68.9) & $33(31.1)$ & \\
\hline$>60$ & $20(58.8)$ & $14(41.2)$ & \\
\hline \multicolumn{4}{|l|}{ Sex } \\
\hline Male & $188(67.4)$ & $91(32.6)$ & 0.81 \\
\hline Female & $176(66.4)$ & $89(33.6)$ & \\
\hline \multicolumn{4}{|l|}{ Race } \\
\hline Chinese & $286(75.3)$ & $94(24.7)$ & $<0.001$ \\
\hline Malay & $60(44.4)$ & $75(55.6)$ & \\
\hline Others & $18(62.1)$ & $11(37.9)$ & \\
\hline \multicolumn{4}{|l|}{ Religion } \\
\hline Buddhism/Taoism & $172(70.5)$ & $72(29.5)$ & $<0.001$ \\
\hline Islam & $63(42.6)$ & $85(57.4)$ & \\
\hline Christianity & $44(83.0)$ & $9(17.0)$ & \\
\hline No religion & 65 (84.4) & $12(15.6)$ & \\
\hline Hindus/others & $20(90.9)$ & $2(9.1)$ & \\
\hline \multicolumn{4}{|l|}{ Completed educational level } \\
\hline No formal education & $9(52.9)$ & $8(47.1)$ & 0.006 \\
\hline Primary & $65(55.1)$ & $53(44.9)$ & \\
\hline Secondary & $155(69.5)$ & $68(30.5)$ & \\
\hline Pre-university, diploma, or tertiary & 135 (72.6) & $51(27.4)$ & \\
\hline
\end{tabular}




\begin{tabular}{|c|c|c|c|}
\hline Demographics & $\begin{array}{l}\text { Multivariate adjusted } \\
\text { odds ratio* }\end{array}$ & $95 \% \mathrm{Cl}$ & p Value \\
\hline \multicolumn{4}{|l|}{ Age (years) } \\
\hline $21-30$ & 1.00 & & \\
\hline $31-40$ & 0.69 & $(0.39$ to 1.25$)$ & 0.22 \\
\hline $41-50$ & 0.45 & $(0.25$ to 0.82$)$ & 0.009 \\
\hline $51-60$ & 0.84 & $(0.43$ to 1.62$)$ & 0.60 \\
\hline$>60$ & 0.52 & $(0.21$ to 1.26$)$ & 0.15 \\
\hline \multicolumn{4}{|c|}{ (0.2) } \\
\hline Male & 1.00 & & \\
\hline Female & 0.90 & $(0.60$ to 1.33$)$ & 0.59 \\
\hline \multicolumn{4}{|l|}{ Religion } \\
\hline Buddhism/Taoism & 1.00 & & \\
\hline Islam & 0.26 & $(0.17$ to 0.41$)$ & $<0.001$ \\
\hline Christianity & 2.00 & $(0.90$ to 4.47$)$ & 0.090 \\
\hline No religion & 2.24 & $(1.12$ to 4.50$)$ & 0.023 \\
\hline Hindus/others & 3.88 & $(0.87$ to 17.30$)$ & 0.076 \\
\hline \multicolumn{4}{|l|}{ Completed educational level } \\
\hline No formal education & 1.00 & & \\
\hline Primary & 1.00 & $(0.33$ to 3.02$)$ & 1.00 \\
\hline Secondary & 2.02 & $(0.68$ to 6.03$)$ & 0.21 \\
\hline Pre-university, diploma, or tertiary & 1.41 & $(0.45$ to 4.49$)$ & 0.56 \\
\hline
\end{tabular}

of corneal donation, followed by the Buddhists or Taoists $(87.2 \%)$, those with no religion $(84.6 \%)$, Muslims $(67.9 \%)$, and Hindus/others $(65.2 \%)(\mathrm{p}<0.001)$.

\section{Responses to specific knowledge questions}

There were a larger proportion of people who were willing to donate their corneas among those who answered the questions correctly. This was statistically significant for four out of the five knowledge questions. People who answered the questions correctly were more likely to donate their corneas than those who answered incorrectly (table 5)

\section{Attitudes}

A total of $96.6 \%$ of all participants thought that corneal donation could help someone to see again. Only $50.8 \%$ would be more willing to donate their corneas if their family members were to receive benefits. Our data show that a more positive attitude towards corneal donation led to increased willingness to donate.

\section{Values}

The relations between instrumental or terminal values and willingness to donate are described in tables 6 and 7 . Participants who were "broadminded" were more likely to donate corneas $(70.5 \%)$ than participants who were not broadminded $(52.6 \%)(\mathrm{p}=0.001)$. Other instrumental values that were statistically significant included "forgiving" $(p=0.022)$, "helpful" $(p=0.013)$, and "loving" $(p=0.022)$. The terminal values "a world of peace" $(p=0.015)$, "family security" ( $p=0.001)$, "happiness" $(p=0.020)$, "inner harmony" $(p=0.003)$, and "true friendship" $(p=0.001)$ were also associated with willingness to donate corneas. A person who thought that world peace was important would be more likely to donate corneas $(68.1 \%)$ than someone who did not think that world peace was important (46.7\%). Therefore, the more altruistic a person was, the greater his willingness to donate his corneas.

\section{Religious and spiritual beliefs}

A total of 54\% of participants thought it was important to be a religious person. Chinese people were less likely to feel that it was important to be a religious person $(59.4 \%)$ than the other ethnic groups (12.6\% for the Malays, and 22.6\% for Indians and other races). People who did not think it was important to be a religious person were more likely to donate their corneas. Forty one per cent of participants believed that luck affects their everyday life. When asked if it was possible to communicate with the dead, only $15 \%$ agreed with the statement (table 8).

\section{DISCUSSION}

In all, $67.0 \%$ of participants were willing to donate their corneas. Willingness to donate was found to be associated with the following characteristics: Chinese, atheist, Hindus/ others, and Christians. The most common reason for donating corneas was willingness to do good. The modified Horton and Horton model ${ }^{5}$ is applicable to corneal donation in Singapore. Increased knowledge (awareness and specific

\begin{tabular}{lllll} 
Table 3 & Reasons affecting one's willingness to donate corneas & & \\
\hline & $\begin{array}{l}\text { Number who } \\
\text { answered this } \\
\text { question }\end{array}$ & $\begin{array}{l}\text { Number who } \\
\text { cited this } \\
\text { reason }\end{array}$ & $\begin{array}{l}\text { Proportion who } \\
\text { cited this } \\
\text { reason (\%) }\end{array}$ & Rank \\
\hline $\begin{array}{l}\text { Reason for willingness to donate corneas } \\
\begin{array}{l}\text { Transplanting a part of you after death will } \\
\text { make you feel that you are doing good }\end{array}\end{array}$ & 364 & 338 & 92.9 & 1 \\
$\begin{array}{l}\text { Heard good results from cornea } \\
\text { transplant operations }\end{array}$ & 364 & 174 & 47.8 & 2 \\
$\begin{array}{l}\text { Read an article or heard a speaker talk } \\
\text { about cornea donations }\end{array}$ & 364 & 171 & 47.0 & 3 \\
$\begin{array}{l}\text { Friend or relative benefited from a cornea } \\
\text { transplant }\end{array}$ & 363 & 67 & 18.5 & 4 \\
Friend or relative donated cornea & 362 & 39 & 10.8 & 5 \\
\hline
\end{tabular}


Table 4 Reasons affecting one's unwillingness to donate corneas

\begin{tabular}{|c|c|c|c|c|}
\hline Reason for unwillingness to donate corneas & $\begin{array}{l}\text { Number who } \\
\text { answered this } \\
\text { question }\end{array}$ & $\begin{array}{l}\text { Number who } \\
\text { cited this } \\
\text { reason }\end{array}$ & $\begin{array}{l}\text { Proportion who } \\
\text { cited this } \\
\text { reason (\%) }\end{array}$ & Rank \\
\hline $\begin{array}{l}\text { Think it is important that body remains } \\
\text { intact after death }\end{array}$ & 179 & 131 & 73.2 & 1 \\
\hline Family would be upset & 179 & 88 & 49.2 & 2 \\
\hline Body would not be treated with proper respect & 179 & 88 & 49.2 & 2 \\
\hline Not sure how cornea would be used & 177 & 85 & 48.0 & 4 \\
\hline Do not like to think about death & 179 & 68 & 38.0 & 5 \\
\hline $\begin{array}{l}\text { Doctors would be anxious to declare } \\
\text { patient dead before he/she actually is }\end{array}$ & 180 & 64 & 35.6 & 6 \\
\hline Can still experience pain after death & 179 & 52 & 29.1 & 7 \\
\hline Might not be able to have a funeral & 180 & 40 & 22.2 & 8 \\
\hline $\begin{array}{l}\text { Heard of poor results from cornea } \\
\text { transplant operations }\end{array}$ & 178 & 38 & 21.9 & 9 \\
\hline
\end{tabular}

knowledge statements), increased altruism (instrumental and terminal values), and a positive attitude towards cornea donation led to an increased willingness to donate.

In our population, it was found that $67 \%$ of the residents were willing to donate their corneas compared with 52\% in adults aged $18-99$ in north western India $(\mathrm{n}=2000)^{1}$ and $44.9 \%$ in adults aged above 15 in Hyderabad, India $(n=2954) .^{2}$ Therefore, the level of willingness towards corneal donation was found to be higher in Singapore than India. ${ }^{12}$ This may be due to greater awareness of corneal donation in Singapore (80.7\%) compared with India (70.5\%, $\left.70.1 \%^{2}\right)$. Higher educational level and greater socioeconomic status in Singapore may also a possible factor. However, the studies may not be directly comparable. The age, ethnicity, and religion distributions of the individuals in the three studies are very different. The two studies in India included

Table 5 Relation between knowledge and attitudes regarding cornea donation and willingness to donate corneas

\begin{tabular}{|c|c|c|c|c|c|c|}
\hline No & Knowledge statements & $\begin{array}{l}\text { Correct } \\
\text { answer }\end{array}$ & $\begin{array}{l}\text { Respondent } \\
\text { answer }\end{array}$ & $\begin{array}{l}\text { Willing to } \\
\text { donate }\end{array}$ & $\begin{array}{l}\begin{array}{l}\text { Unwilling to } \\
\text { donate }\end{array} \\
\text { No }(\%)\end{array}$ & p Value \\
\hline 1 & $\begin{array}{l}\text { After a patient has been certified brain dead, there } \\
\text { is still a possibility that he can recover and return } \\
\text { back to normal daily functions }\end{array}$ & False & $\begin{array}{l}\text { Correct } \\
\text { Incorrect }\end{array}$ & $\begin{array}{l}245(67.7) \\
109(67.8)\end{array}$ & $\begin{array}{r}117(32.3) \\
52(32.3)\end{array}$ & 0.10 \\
\hline 2 & $\begin{array}{l}\text { The donor's family does not have to pay for the } \\
\text { hospital and surgery costs for removing, } \\
\text { preserving, and transporting the donor's corneas }\end{array}$ & True & $\begin{array}{l}\text { Correct } \\
\text { Incorrect }\end{array}$ & $\begin{array}{r}278(71.8) \\
72(56.7)\end{array}$ & $\begin{array}{r}109(28.2) \\
55(43.3)\end{array}$ & 0.001 \\
\hline 3 & $\begin{array}{l}\text { Organ donation generally does not result in any } \\
\text { significant delay in normal funeral arrangements }\end{array}$ & True & $\begin{array}{l}\text { Correct } \\
\text { Incorrect }\end{array}$ & $\begin{array}{l}250(73.1) \\
103(58.5)\end{array}$ & $\begin{array}{l}92(26.9) \\
73(41.5)\end{array}$ & 0.001 \\
\hline 4 & $\begin{array}{l}\text { A donor's family can request compensation to } \\
\text { offset the cost of the donor's burial or cremation }\end{array}$ & False & $\begin{array}{l}\text { Correct } \\
\text { Incorrect }\end{array}$ & $\begin{array}{r}253(71.9) \\
96(60.4)\end{array}$ & $\begin{array}{l}99(28.1) \\
63(39.6)\end{array}$ & 0.010 \\
\hline 5 & $\begin{array}{l}\text { Corneal donation after death leaves the body } \\
\text { mutilated and disfigured }\end{array}$ & False & $\begin{array}{l}\text { Correct } \\
\text { Incorrect }\end{array}$ & $\begin{array}{r}289(75.1) \\
66(46.8)\end{array}$ & $\begin{array}{l}96(24.9) \\
75(53.2)\end{array}$ & $<0.001$ \\
\hline 6 & Cornea donation can help someone see again & - & $\begin{array}{l}\text { Agree } \\
\text { Disagree }\end{array}$ & $\begin{array}{c}359(69.2) \\
1(5.6)\end{array}$ & $\begin{array}{r}160(30.8) \\
17(94.4)\end{array}$ & $<0.001$ \\
\hline 7 & $\begin{array}{l}\text { More willing to donate corneas if family } \\
\text { members were to receive benefits after that }\end{array}$ & - & $\begin{array}{l}\text { Agree } \\
\text { Disagree }\end{array}$ & $\begin{array}{l}202(74.0) \\
160(60.6)\end{array}$ & $\begin{array}{r}71(26.0) \\
104(39.4)\end{array}$ & 0.001 \\
\hline
\end{tabular}

Table 6 Relation between instrumental values and willingness to donate corneas

\begin{tabular}{|c|c|c|c|c|c|}
\hline & & & Willing to donate & Unwilling to donate & \\
\hline Number & Instrumental values* & Importance & No $(\%)$ & No (\%) & p Value \\
\hline \multirow[t]{2}{*}{1} & Broadminded & No & $51(52.6)$ & $46(47.4)$ & 0.001 \\
\hline & & Yes & $313(70.5)$ & $131(29.5)$ & \\
\hline \multirow[t]{2}{*}{2} & Cheerful & No & $23(56.1)$ & $18(43.9)$ & 0.13 \\
\hline & & Yes & $341(67.8)$ & $162(32.2)$ & \\
\hline \multirow[t]{2}{*}{3} & Courageous & No & $61(60.4)$ & $40(39.6)$ & 0.12 \\
\hline & & Yes & $303(68.6)$ & $139(31.4)$ & \\
\hline \multirow[t]{2}{*}{4} & Forgiving & No & $25(52.1)$ & $23(47.9)$ & 0.22 \\
\hline & & Yes & $339(68.3)$ & $157(31.7)$ & \\
\hline \multirow[t]{2}{*}{5} & Helpful & No & $22(50.0)$ & $22(50.0)$ & 0.013 \\
\hline & & Yes & $342(68.4)$ & $158(31.6)$ & \\
\hline \multirow[t]{2}{*}{6} & Honest & No & $18(52.9)$ & $16(47.1)$ & 0.074 \\
\hline & & Yes & $346(67.8)$ & $164(32.2)$ & \\
\hline \multirow[t]{2}{*}{7} & Loving & No & $19(50.0)$ & $19(50.0)$ & 0.022 \\
\hline & & Yes & $344(68.1)$ & $161(31.9)$ & \\
\hline
\end{tabular}

The missing values for questions 1,3 , and 7 are 3,1 , and 1 respectively.

*Instrumental values refer to the means of achieving the desired end states of existence. 


\begin{tabular}{|c|c|c|c|c|c|}
\hline & & & Willing to donate & Unwilling to donate & \\
\hline Number & Terminal values & Importance & No (\%) & № (\%) & p Value \\
\hline 1 & A world of peace & $\begin{array}{l}\text { No } \\
\text { Yes }\end{array}$ & $\begin{array}{r}14(46.7) \\
350(68.1)\end{array}$ & $\begin{array}{r}16(53.3) \\
164(31.9)\end{array}$ & 0.015 \\
\hline 2 & Equality & $\begin{array}{l}\text { No } \\
\text { Yes }\end{array}$ & $\begin{array}{r}28(60.9) \\
335(67.4)\end{array}$ & $\begin{array}{l}18(39.1) \\
162(32.6)\end{array}$ & 0.37 \\
\hline 3 & Family security & $\begin{array}{l}\text { No } \\
\text { Yes }\end{array}$ & $\begin{array}{r}4(26.7) \\
360(68.1)\end{array}$ & $\begin{array}{r}11(73.3) \\
169(31.9)\end{array}$ & 0.001 \\
\hline 4 & Freedom & $\begin{array}{l}\text { No } \\
\text { Yes }\end{array}$ & $\begin{array}{r}26(55.3) \\
338(68.1)\end{array}$ & $\begin{array}{r}21(44.7) \\
158(31.9)\end{array}$ & 0.074 \\
\hline 5 & Happiness & $\begin{array}{l}\text { No } \\
\text { Yes }\end{array}$ & $\begin{array}{r}7(41.2) \\
357(68.0)\end{array}$ & $\begin{array}{r}10(58.8) \\
168(32.0)\end{array}$ & 0.020 \\
\hline 6 & Inner harmony & $\begin{array}{l}\text { No } \\
\text { Yes }\end{array}$ & $\begin{array}{r}16(44.4) \\
346(68.4)\end{array}$ & $\begin{array}{r}20(55.6) \\
160(31.6)\end{array}$ & 0.003 \\
\hline 7 & Self respect & $\begin{array}{l}\text { No } \\
\text { Yes }\end{array}$ & $\begin{array}{r}23(59.0) \\
341(67.8)\end{array}$ & $\begin{array}{r}16(41.0) \\
162(32.2)\end{array}$ & 0.26 \\
\hline 8 & True friendship & $\begin{array}{l}\text { No } \\
\text { Yes }\end{array}$ & $\begin{array}{r}19(44.2) \\
344(68.8)\end{array}$ & $\begin{array}{r}24(55.8) \\
156(31.2)\end{array}$ & 0.001 \\
\hline 9 & Wisdom & $\begin{array}{l}\text { No } \\
\text { Yes }\end{array}$ & $\begin{array}{r}34(57.6) \\
330(68.0)\end{array}$ & $\begin{array}{r}25(42.4) \\
155(32.0)\end{array}$ & 0.11 \\
\hline
\end{tabular}

The missing values for questions $2,4,5,6,7$, and 8 are 1, 1, 2, 2, 2, and 1 respectively.

*Terminal values refer to the desired end states of existence that are worth attaining. ${ }^{7}$

individuals from a wider age range and the majority of their participants were Hindus. In contrast, majority of the participants in our study were Buddhists or Taoist $(44.9 \%)$ and only $3.0 \%$ are Hindus. The study populations from the two countries are different in both their cultural and socioeconomical background.

In all, $92.9 \%$ of participants who were willing to donate cited doing good as the reason. This was in contrast with the study done in Toronto ${ }^{3}$ where the main reasons were personal experiences with cornea donation and transplants, and good results from corneal transplant operations. This could be due to the effective use of a well established eye bank in Toronto. More corneal transplant operations were carried out annually in Toronto than Singapore (1200 transplants are done in Toronto annually compared to 994 done so far in Singapore from 1996 to 2001). In north western India, ${ }^{1}$ the main reason for willingness to donate was the possibility of living on after death if they donated their corneas. This may reflect their belief of life after death.

On the other hand, the main reason for unwillingness to donate in our study was the belief that it was important to have an intact body after passing away. ${ }^{8}{ }^{9}$ This could be for religious or cultural reasons. The main reason for unwillingness in Toronto ${ }^{3}$ and Hyderabad ${ }^{2}$ was religion, while that in north western India ${ }^{1}$ was the concern with hurting their family members. In our study, it was found that one's parents and spouse have a strong influence on one's decision in becoming a potential corneal donor. This may be reflective of the prevalent societal family values in Singapore.

The modified Horton and Horton model ${ }^{5}$ was found to be applicable to corneal donation in Singapore. It postulates that increased knowledge, increased altruism, weaker spiritual beliefs, and a positive attitude towards corneal donation are positive predictors for willingness to donate. We found that an increase in knowledge leads to a greater willingness to donate. Knowledge consists of awareness and factual knowledge; $80.7 \%$ of our participants had heard of cornea donation, compared with $98 \%$ in Toronto ${ }^{3}$ and $61.0 \%$ to $70.5 \%$ in Puerto Rico $^{6}$ and India. ${ }^{12}$ The difference could be due to the higher literacy rate and better health promotion programmes in Toronto and insufficient resources for health promotion in India and Puerto Rico.

In Singapore, the lack of available corneas precludes availability of corneas for emergency corneal transplants. Bullous keratopathy is one of the most common indications for cornea transplant in Singapore. Statistics show that in the year 2003, about 60 transplanted corneas were acquired from local donors but the bulk of the transplanted corneas (108) were foreign, coming mainly from the United States and Sri Lanka. These figures reflect Singapore's lack of self sufficiency in the provision of transplantable corneas for patients.

This study is a population based study in a multiracial Asian society. Face to face interviews were conducted with the questionnaire formulated based on the modified Horton and Horton model, ${ }^{5}$ a focus group discussion, and a pilot study. However, there are limitations to this study that need to be considered when interpreting the results. Our study population may not be entirely representative of the entire Singapore population. Age and sex distributions are fairly similar to the Singapore population (Singapore Census, 2000). However, there were larger proportions of Malays and Muslims in our study. Our participants were also better

Table 8 Relation between religious beliefs and willingness to donate corneas

\begin{tabular}{|c|c|c|c|c|}
\hline \multirow[b]{2}{*}{ Belief } & & $\begin{array}{l}\text { Willing to } \\
\text { donate cornea }\end{array}$ & $\begin{array}{l}\text { Unwilling to donate } \\
\text { cornea }\end{array}$ & \multirow[b]{2}{*}{ p Value } \\
\hline & & No (\%) & No (\%) & \\
\hline \multirow{3}{*}{$\begin{array}{l}\text { It is important to be a } \\
\text { religious person }\end{array}$} & Disagree & 81 (82.7) & 17 (17.3) & \multirow[t]{3}{*}{$<0.001$} \\
\hline & Neutral & $108(72.0)$ & $42(28.0)$ & \\
\hline & Agree & $174(59.0)$ & $121(41.0)$ & \\
\hline \multirow{3}{*}{$\begin{array}{l}\text { You have religious beliefs } \\
\text { that provide meaning and } \\
\text { purpose to life }\end{array}$} & Disagree & $62(75.6)$ & $20(24.4)$ & \multirow[t]{3}{*}{0.20} \\
\hline & Neutral & 81 (65.9) & $42(34.1)$ & \\
\hline & Agree & $220(65.3)$ & $117(34.7)$ & \\
\hline
\end{tabular}


educated. Hence, our prevalence rate may be different from the true prevalence rate of Singapore. Results may also be skewed because of non-participation bias. Those who participated in our study may have a higher level of awareness about corneal donation or greater altruistic values. However, our participation rate is $65.9 \%$, which is fairly high. Characteristics such as age and sex are also very similar among the participants and non-participants. Non-participation is also minimised with measures such as distributing cover letters and re-visiting households at least three other times on different days.

Public education programmes via primary care physician, mass media, health campaigns in community and schools, and religious talks may be implemented to increase awareness and knowledge of corneal donation. Misconceptions about corneal donation issues such as brain death and organ use may also be clarified.

\section{CONCLUSION}

Our study showed that $67.0 \%$ were willing to donate their corneas. Respondents who are the least willing to donate their corneas are the Malays and Muslims. The main reason for unwillingness to donate corneas is the importance that the body remains intact after death $(73.2 \%)$. Our study also showed that Singapore adults' awareness of corneal donation was high; $80.5 \%$ of participants had heard of cornea donation.

\section{ACKNOWLEDGEMENTS}

We wish to acknowledge the National University of Singapore Community Health Project Group 42004 third year medical students who conducted this survey: Alagappan U, Ang KX, Ang Y, Chan KW, Chan LH, Cheok LZ, Chuah SY, Chutatape A, Kee SC, Koh XL, Lim
SL, Lim YJ, Lim ZL, Lin HA, Liu SL, Loh KY, Mathews I, Ng LC, Ng KP, Ong AH, Ong KL, Ong YM, Pang SY, Parekh PV, Phua BK, Phua M, Sahaya N, Tan HT, Tee HW, Wang TJ, Wong HK, Wong ST, Wong ZW, Xu HY, Yang LQ, Yang PL, Yeo YW.

\section{Authors' affiliations}

Y-W Yew, S-M Saw, H-M Shen, M-S Yew, Department of Community, Occupational and Family Medicine, National University of Singapore, 16 Medical Drive, Singapore 117597

J C-H Pan, W-J Heng, Department of Ophthalmology, Tan Tock Seng Hospital, 11 Jalan Tan Tock Seng, Singapore 308433

M Lwin, NUS Business School, Department of Marketing, 1 Business

Link, Singapore 117592

\section{REFERENCES}

1 Duggal M, Brar GS, Prasad VS, et al. Public attitude toward eye donation in NW India. Transplant Proc 2003;35:19-20.

2 Dandona R, Dandona L, Naduvilath TJ, et al. Awareness of eye donation in an urban population in India. Aust N Z J Ophthalmol 1999;27:166-9.

3 Basu PK, Hazariwala KM, Chipman ML. Public attitudes towards donation of body parts, particularly the eye. Canadian Ophthalmol 1989;24:216-20.

4 Horton RL, Horton PJ. A model of willingness to become a potential organ donor. Soc Sci Med 1991;33:1037-51.

5 Lwin MO, Williams JD, Lan LL. Social marketing initiatives: National Kidney Foundation's organ donation programs in Singapore. J Public Policy Marketing 2002;21:66-77.

6 Dominguez JM, Gonzalez ZA, Morales Otero LA, et al. Knowledge and attitude about organ donation in a Hispanic population. Transplant Proc $1991 ; 23: 1804-6$.

7 Bilgel H, Bilgel N, Okan N, et al. Public attitudes toward organ donation. Transplant Int 1991:4:243-5.

8 Rasheed HZ. Organ donation and transplantation-a Muslim viewpoint. Transplant Proc 1992;24:21 16-17.

9 Lam WA, McCullough LB. Influence of religious and spiritual values on the willingness of Chinese-Americans to donate organs for transplantation. Clin Transplant 2000;14:449-56. 